\title{
Balanced Sediment Fluxes in Southern California's Mediterranean-Climate Zone Salt Marshes
}

\author{
Jordan A. Rosencranz ${ }^{1,7}$ • Neil K. Ganju ${ }^{2}$. Richard F. Ambrose ${ }^{1,3}$. \\ Sandra M. Brosnahan ${ }^{2} \cdot$ Patrick J. Dickhudt ${ }^{4} \cdot$ Glenn R. Guntenspergen ${ }^{5}$ • \\ Glen M. MacDonald ${ }^{1,6}$ • John Y. Takekawa ${ }^{7,8} \cdot$ Karen M. Thorne $^{7}$
}

Received: 23 March 2015 /Revised: 5 November 2015 / Accepted: 20 November 2015 / Published online: 1 December 2015

(C) The Author(s) 2015. This article is published with open access at Springerlink.com

\begin{abstract}
Salt marsh elevation and geomorphic stability depends on mineral sedimentation. Many Mediterraneanclimate salt marshes along southern California, USA coast import sediment during El Niño storm events, but sediment fluxes and mechanisms during dry weather are potentially important for marsh stability. We calculated tidal creek sediment fluxes within a highly modified, sediment-starved, 1.5$\mathrm{km}^{2}$ salt marsh (Seal Beach) and a less modified $1-\mathrm{km}^{2}$ marsh (Mugu) with fluvial sediment supply. We measured salt marsh plain suspended sediment concentration and vertical accretion using single stage samplers and marker horizons. At Seal Beach, a 2014 storm yielded 39 and $28 \mathrm{~g} / \mathrm{s}$ mean sediment fluxes and imported 12,000 and $8800 \mathrm{~kg}$ in a western and
\end{abstract}

Communicated by Carl T. Friedrichs

Jordan A. Rosencranz

jrosencranz@usgs.gov

1 Institute of the Environment and Sustainability, University of California, Los Angeles, CA 90095, USA

2 US Geological Survey, Woods Hole Coastal, and Marine Science Center, Woods Hole, MA 02556, USA

3 Department of Environmental Health Sciences, University of California, Los Angeles, CA 90095-1772, USA

4 US Army Corps of Engineers, Field Research Facility, Kitty Hawk, NC 27949-4472, USA

5 US Geological Survey, Patuxent Wildlife Research Center, Superior, WI 54880, USA

6 Department of Geography, University of California, Los Angeles, CA 90095-1524, USA

7 US Geological Survey, Western Ecological Research Center, San Francisco Bay Estuary Field Station, Vallejo, CA 94592, USA

8 National Audubon Society, Science Division, 220 Montgomery Street, San Francisco, CA 94104, USA eastern channel. Western channel storm imports offset $8700 \mathrm{~kg}$ exported during 2 months of dry weather, while eastern channel storm imports augmented $9200 \mathrm{~kg}$ imported during dry weather. During the storm at Mugu, suspended sediment concentrations on the marsh plain increased by a factor of four; accretion was 1-2 mm near creek levees. An exceptionally high tide sequence yielded $4.4 \mathrm{~g} / \mathrm{s}$ mean sediment flux, importing $1700 \mathrm{~kg}$ : $20 \%$ of Mugu's dry weather fluxes. Overall, low sediment fluxes were observed, suggesting that these salt marshes are geomorphically stable during dry weather conditions. Results suggest storms and high lunar tides may play large roles, importing sediment and maintaining dry weather sediment flux balances for southern California salt marshes. However, under future climate change and sea level rise scenarios, results suggest that balanced sediment fluxes lead to marsh elevational instability based on estimated mineral sediment deficits.

Keywords Suspended sediment fluxes - Vertical accretion . Mediterranean climate $\cdot$ Tidal creeks $\cdot$ Salt marshes

\section{Introduction}

Sediment transport to salt marsh complexes is driven by tidal and storm forcing, external sediment input, internal sediment redistribution, and trapping of sediment by marsh vegetation. Sediment dynamics are key components of elevation and geomorphic stability for salt marshes in the face of sea level rise (SLR). Although salt marshes are inherently resilient to storms and low rates of SLR (Redfield 1972; Kirwan and Murray 2007; Kirwan and Mudd 2012), human development of the landscape has modified the availability of external sediment for accretion for many salt marshes. These landscape modifications can leave salt marshes without a natural 
mechanism and sediment source to adjust to future perturbations. Salt marsh loss has been shown to result from past alterations to rivers and sediment delivery (Day et al. 2000, 2011; Mudd 2011).

In Mediterranean-climate regions such as southern California, USA, the long-term effects of sediment alterations on salt marshes are poorly understood, with a few notable exceptions including the sediment-rich Tijuana Estuary (Cahoon et al. 1996; Wallace et al. 2005) and Mugu Lagoon (Onuf 1987). Over the past 200 years, sedimentation rates have increased in some southern California marshes (Mudie and Byrne 1980; Davis 1992) that have imported the majority of sediment during El Niño events when coastal zone sediment loads are typically high (Warrick and Farnsworth 2009b). However, recent sediment fluxes and the mechanisms driving them during dry seasons and droughts have not been well documented. While catchment-wide drainage density, storm runoff, and associated suspended sediment concentrations have likely increased in Tijuana Estuary (compared to their pre-European state), other marshes in southern California have lost portions of their historic terrestrial watersheds due to urbanization and flood control projects (Brownlie and Taylor 1981; Stein et al. 2007; Grossinger et al. 2011).

Salt marshes seaward of extensively developed basins are often targets for management and restoration actions but are facing a range of 0.42 and $1.67 \mathrm{~m}$ of SLR by 2100 (National Resource Council 2012). Mineral sediment import, in addition to organic matter accumulation via plant production (Kirwan and Mudd 2012; Graham and Mendelssohn 2014), is necessary to maintain the geomorphic stability of tidal channels, intertidal flats, and salt marsh plains. To understand the mechanisms of this stability in light of changing climates, especially if future droughts become more prolonged and the propensity for El Niño events decreases (MacDonald and Case 2005; MacDonald et al. 2008), there is a need to assess the fate and transport of suspended sediment in southern California salt marshes. Ganju et al. (2013) proposed a conceptual model of salt marsh stability that is based on sediment source, wetland channel location, and transport mechanisms. The primary aim of this study was to apply this conceptual model in two southern California Mediterranean-climate salt marshes that have different levels of modifications (Figs. 1 and 2). Our objectives were to quantify storm-related and nonstorm-related mineral sediment budgets and describe the mechanisms driving sediment fluxes during drought in contrasting southern California salt marshes: one with a large terrestrial sediment source and one that has no watershed sediment source. Quantifying and understanding sediment fluxes and assessing mechanisms that determine stability during droughts will be valuable for long-term resource management and future restoration of salt marshes in the face of SLR and climate change.
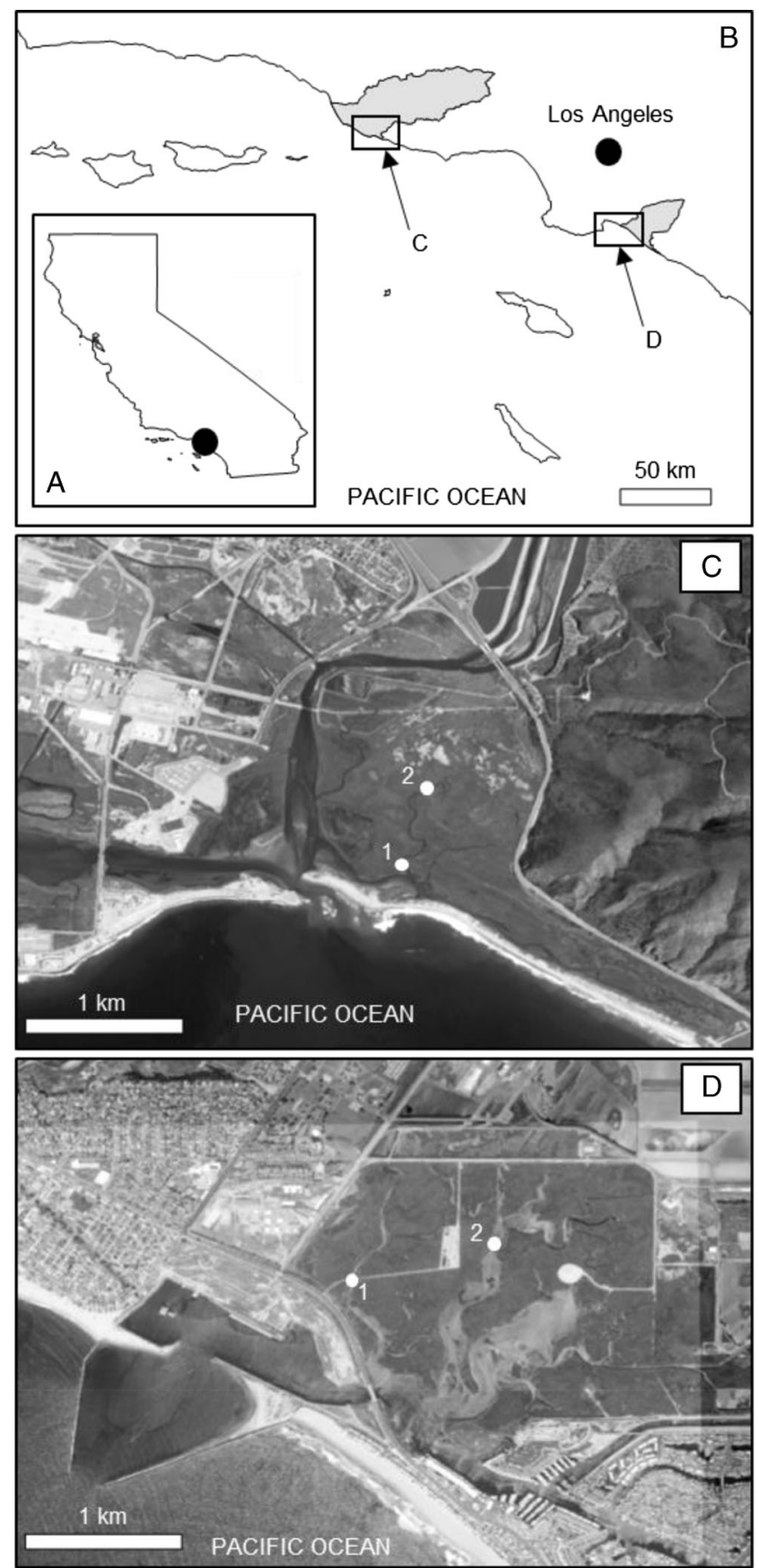

Fig. 1 Site map of study areas. Regional setting in California (center inset; a), location of terrestrial watershed basins (grey polygons) of Mugu and Seal Beach (b). Numbers represent locations of turbidity and sediment flux instruments for Mugu (c) and Seal Beach (d)

\section{Regional Setting}

The central basin of Mugu Lagoon (Mugu) is part of a threebranched estuary occurring in the flat valley bottom of the Oxnard plain (Fig. 2). The plain is characterized by deep alluvial soils, while the adjacent Transverse Ranges are steep and highly erodible sedimentary and igneous slopes (Brownlie and Taylor 1981). Temperatures are mild year- 
Fig. 2 Illustrations of conceptual model of marsh stability for Mugu wetland complex and Seal Beach wetland complex. While Seal Beach relies on a marine source, Mugu has coastal and fluvial sources of sediment Mobilization and advection occurs in both marshes during spring tides and storm surge events within the salt marshes
Seal Beach

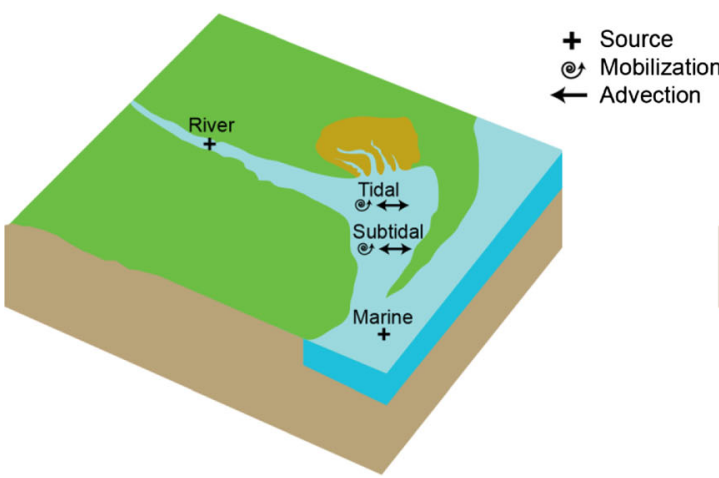

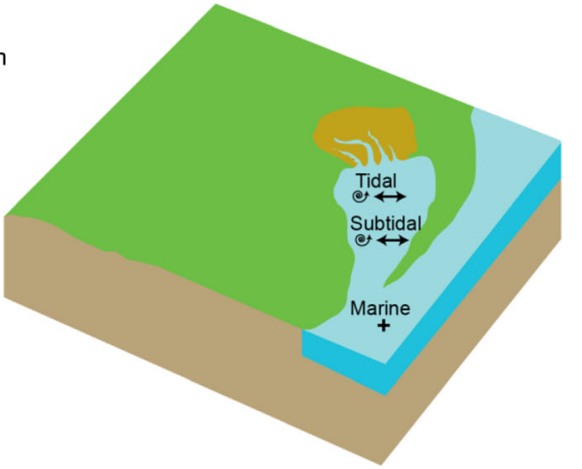

round, with the majority of annual precipitation falling between the months of November and April. Monthly average January and July high temperatures are 19 and $23{ }^{\circ} \mathrm{C}$, respectively, and mean annual precipitation is $40 \mathrm{~cm}$ (usclimatedata.com). However, it is not uncommon for a single storm to surpass the annual average of precipitation (Onuf 1987). Exceptionally large creek flows can occur during storms within the free-flowing, $640-\mathrm{km}^{2}$ Calleguas Creek, which is adjacent to the salt marsh plain of Mugu (Fig. 1). Although approximately $54 \%$ of the southern California watershed is controlled by dams, this region of southern California has relatively few dams (Willis and Griggs 2003). A combination of steep slopes and intense, isolated periods of rainfall have yielded daily averaged suspended sediment concentration beyond $70,000 \mathrm{mg} / \mathrm{L}$ several times throughout the stream gauge record (Warrick and Farnsworth 2009a). While these concentrations may reflect the conditions of a natural southern California watershed during the wet season, dry season conditions are not likely representative of pre-European conditions when the Calleguas Creek drainage density was much smaller and dry season flows typically did not reach the estuary (Beller et al. 2011). For example, point source runoff from wastewater treatment plants and construction projects, as well as non-point source runoff from agriculture, can augment dry weather flows in the creek.

The salt marsh plain of Mugu is approximately $1 \mathrm{~km}^{2}$ in size and dominated by a diversity of shrubby salt marsh vegetation types including pickleweed (Sarcocornia pacifica) and salt grass (Distichlis spicata). Tides are mixed semi-diurnal, and predicted maximum tide range from a nearby tide gauge was $2.6 \mathrm{~m}$ for 2013 (Mugu Lagoon Ocean Pier; http:// tidesandcurrents.noaa.gov/tide_predictions.html). Mugu is also home to one of the largest breeding populations of Belding's savannah sparrow (Passerculus sandwichensis beldingi) (Zembal and Hoffman 2010), a California statelisted endangered species, making it an important area for future management in the face of SLR.

The US Fish \& Wildlife Service's Seal Beach National Wildlife Refuge (Seal Beach) is part of the historic Anaheim
Bay wetlands network and occurs in a flood plain that drains the steep and highly erodible Transverse Ranges (Brownlie and Taylor 1981). Monthly, January and July high temperatures average 20 and $28^{\circ} \mathrm{C}$ and mean annual precipitation is $31 \mathrm{~cm}$ (usclimatedata.com). Before the early twentieth century, the braided channels of the Santa Ana and San Gabriel Rivers once discharged large amounts of sediment into Anaheim Bay near and through Seal Beach salt marsh (Brownlie and Taylor 1981; Stein et al. 2007; Warrick and Farnsworth 2009b); however, flood control efforts have channelized these rivers so that storm flows quickly discharge into the Pacific Ocean without passing through the salt marshes. Seal Beach is also sheltered from energetic waves of Pacific Ocean by extensive, well-developed, sandy beaches, as well as human infrastructure (e.g., the Pacific Coast Highway).

Seal Beach is approximately $1.5 \mathrm{~km}^{2}$ (Fig. 1). Predicted maximum tide range from a nearby tide gauge was $2.7 \mathrm{~m}$ for 2013 (Long Beach Terminal Island; http://tidesandcurrents. noaa.gov/tide_predictions.html). At its higher elevations, Seal Beach has shrubby salt marsh vegetation, including pickleweed, but in the lower elevations and adjacent to tidal creeks, it is dominated by cordgrass (Spartina foliosa). Seal Beach is managed for migratory birds and protected species, which include the federally endangered Light-footed Ridgway's Rail (Rallus obsoletus levipes) (Zembal et al. 2013).

In comparison, Seal Beach is located within a densely developed and urbanized region, whereas Mugu is adjacent to open uplands and drains a river system. While the subsidence history of Mugu is unknown, Seal Beach has subsided between 16 and $25 \mathrm{~cm}$ from 1968 to 2012, probably due to oil and groundwater extraction (Takekawa et al. 2014). Both Mugu and Seal Beach represent modified landscapes that include watershed level modifications and altered sedimentation patterns, making them ideal sites for studying the range of sediment flux patterns and mechanisms representative of southern California salt marshes. 


\section{Methods}

We placed instruments in two sites within one channel at Mugu from 10 April to 10 November 2013 and two channels at Seal Beach from 25 February to 22 May 2014 to measure sediment fluxes (Fig. 1). Monitoring periods were constrained by protection of seasonal breeding by Light-footed Ridgway's Rails and Belding's Savannah sparrows. However, at both sites, the monitoring periods captured a significant storm event. In both cases, these were non-El Niño periods with average Multivariate El Niño Southern Oscillation Index values of -0.2 and 0.5 (http://www.esrl.noaa.gov/psd/enso/ mei/index.html) and Sea Surface Temperature anomalies in NINO 3.4 Index of -0.2 and -0.02 (LIM SST Anomalies Forecast data provided by the NOAA/ESRL Physical Science Division and CIRES CU, Boulder, Colorado at http://www.esrl.noaa.gov/psd/). With optical turbidity and acoustic water current sensors situated approximately $1 \mathrm{~km}$ landward from the estuary mouth in a 0.75 -m deep, 10 -m wide channel, we instrumented site Mugu1 to measure sediment fluxes, which includes suspended sediment and water fluxes, at 20-min intervals. Site Mugu2 was instrumented to measure only suspended sediment concentration, also at 20-min intervals, and situated $1.7 \mathrm{~km}$ landward in a shallower channel that became dry during low tides. Site Seal Beach1 was $1.7 \mathrm{~km}$ landward from the estuary mouth in a 2-m deep, 35-m wide channel, while Seal Beach2 was over $2 \mathrm{~km}$ landward in a 3.5$\mathrm{m}$ deep, 40-m wide channel. Both Seal Beach1 and Seal Beach2 were equipped to measure sediment fluxes at 15-min intervals.

\section{Continuous Tidal Water Fluxes and Suspended Sediment Concentration}

For calculating tidal water fluxes $\left(Q_{i}\right)$ and calibrating nephelometric turbidity units (NTU) to suspended sediment concentration, we followed the methods of Ganju et al. (2013). At Mugu1, Seal Beach1, and Seal Beach2, we deployed Nortek Aquadopp acoustic Doppler current profilers (ADCP) at $0.17 \mathrm{~m}$ above the bottom of the channel to measure continuous index velocity $\left(v_{i}\right)$, an instantaneous streamwise velocity, and water level $(h)$. Due to the small size of the channel, we assumed that $v_{c a}$ was similar to $v_{i}$ at Mugu1, while we used measurements to assess the relationship between $v_{i}$ and $v_{c a}$ for the larger channels at Seal Beach. In addition to deploying the Nortek Aquadopp ADCP for Seal Beach1 and Seal Beach2, cross-sectionally averaged velocity $\left(v_{\mathrm{ca}}\right)$ and channel area $(a)$ were measured on 14 and 15 February 2014 using a tethered boat carrying a Teledyne RDI, Rio Grande $1200 \mathrm{kHz}$ ADCP towed cross-channel, while $v_{c a}$ and $a$ were estimated at Mugu assuming a parabolic channel and uniform velocity distribution. Continuous turbidity measurements were collected at Mugu1 and Mugu2 with YSI 6920 sondes and at Seal
Beach1 and Seal Beach2 with YSI 6600 sondes (YSI). Finally, to calibrate NTU to suspended sediment concentration, water samples were collected near all YSI sensors with Van Dorn samplers and $1 \mathrm{~L}$ Nalgene bottles via repeated median linear calibration method (Helsel and Hirsch 1992) (Fig. 3). All turbidity time series were converted to suspended sediment concentration.

There are various factors that can impact the association between turbidity and suspended sediment concentration. Particle size, shape, composition, bubbles, biological fouling, and color can impact the amount of light scattered and the accuracy of the turbidity measurement (Sutherland et al. 2000; Downing 2006). Microorganism activity can also increase uncertainty in the estimation of suspended sediment concentration (Rasmussen et al. 2009). In this study, it is assumed that these impacts are negligible and did not impact the calibration. We also assume that these sources of variability are incorporated in local calibration against water samples and that the calibration holds for the entire monitoring duration.

\section{Sediment Flux Decomposition}

We decomposed the sediment flux time series into advective, dispersive, and Stokes drift flux components to determine mechanisms that drive sediment fluxes on tidal and subtidal timescales (Dyer 1974). While atmospheric and riverine events are typically represented by advective fluxes, high frequency tidal influence is characterized by dispersive components. Lastly, Stokes drift flux is strong when velocity and channel area are correlated (Ganju and Schoellhamer 2006).

Sediment fluxes $\left(Q_{s}\right)$ are computed as the product of mean channel velocity $\left(u\right.$, or $\left.v_{c a}\right)$, suspended sediment concentration $(c)$, and channel area $(a)$ :

$Q_{s}=u^{*} a^{*} c$

where

$u=u^{\prime}+[u]$

$a=a^{\prime}+[a]$

$c=c^{\prime}+[c]$

Brackets represent the tidally averaged value, which is calculated by using a $30-\mathrm{h}$, low-pass filter, which uses a threepoint taper between pass band and stop band to remove tidal signals; the prime represents a deviation of the instantaneous value from the tidal average. Substitution of Eqs. (2-4) into Eq. (1) produces eight individual components of sediment fluxes in the following equation:

$$
\begin{aligned}
Q_{s}= & {[u][a][c]+u^{\prime}[a] c^{\prime}+u^{\prime} a^{\prime}[c]+u^{\prime} a^{\prime}[c]+u^{\prime} a^{\prime} c^{\prime} } \\
& +[u][a] c^{\prime}+[u] a^{\prime} c^{\prime}+[u] a^{\prime}[c]
\end{aligned}
$$


Fig. 3 Turbidity-to-suspended sediment concentration calibration for Mugu (top left) and Seal Beach (top right). Suspended sediment concentration time series is shown for Mugu (bottom left) and Seal Beach (bottom right). Grey dots (top) and grey lines (bottom) represent Mugu1 (left) and Seal Beach2 (right), while black dots (top) and black lines (bottom) represent Mugu2 (left) and Seal Beach1 (right)
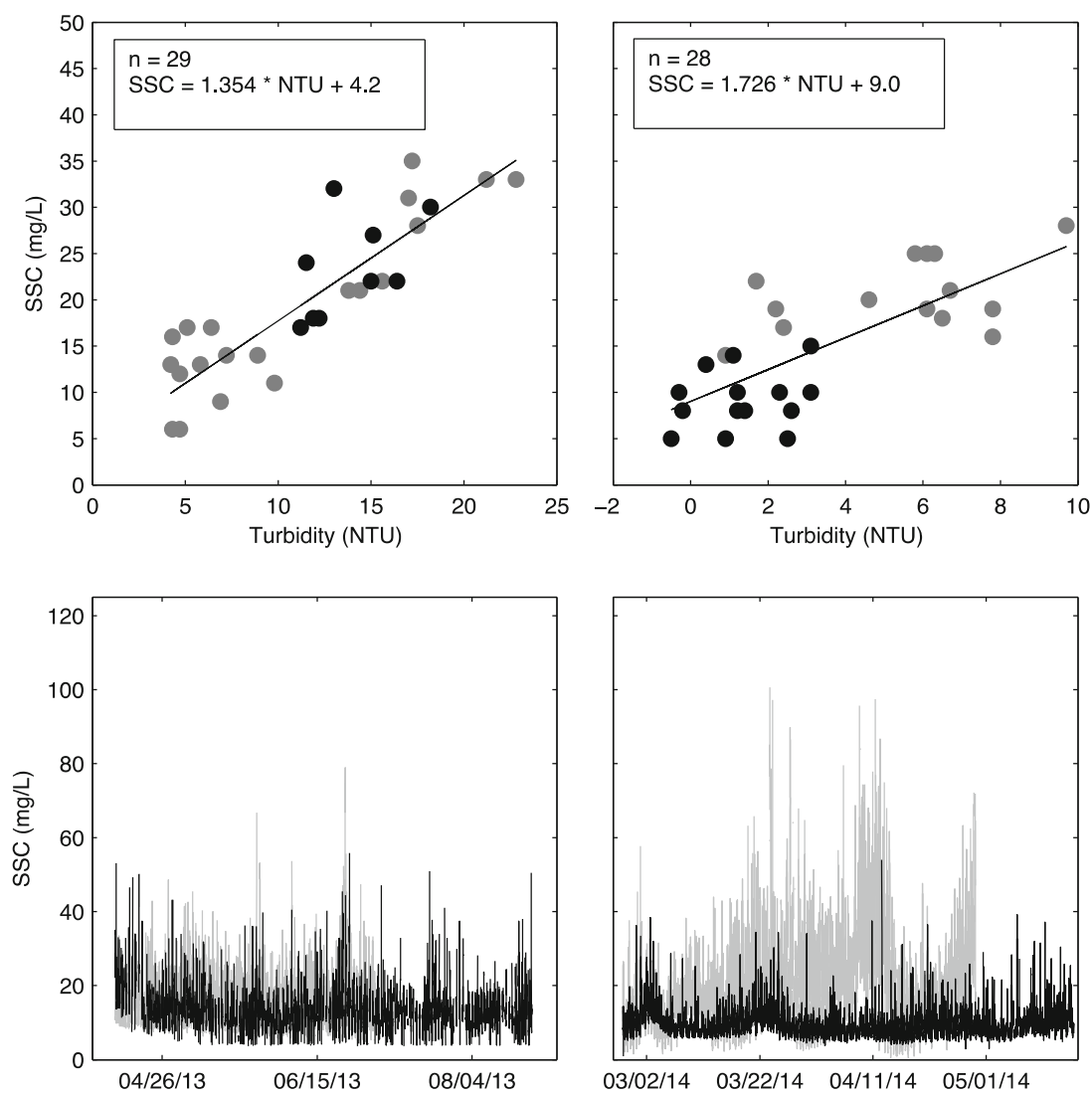

where $[u][a][c]$ is the advective flux, $u^{\prime}[a] c^{\prime}$ is the dispersive flux, and $u^{\prime} a^{\prime}[c]$ is Stokes drift flux; these three terms typically dominate in estuarine systems (Geyer et al. 2001; Ganju et al. 2005). However, because of low tide range and the infrequency of storms in southern California salt marshes, it is likely that these components are negligible most of the time.

\section{Calculation of Potential Mineral Accretion and Deficits}

Following the method of Ganju et al. (2013), we calculated a potential mineral accretion rate $\left(M A_{p} ; \mathrm{mm} / \mathrm{year}\right)$ with the following steps. First, we calculated a rough estimate of the salt marsh drainage area $\left(\mathrm{DA} ; \mathrm{m}^{2}\right.$ ) for each tidal creek basin, using aerial imagery (http://www.earthpoint.us/Shapes.aspx). Then, we combined our estimate of DA with measured bulk density (BD) from top $10 \mathrm{~cm}$ of previously collected soil cores from Mugu $\left(630 \mathrm{~kg} / \mathrm{m}^{3} ; n=3\right.$; Elgin and Ambrose, unpublished data, 2012) and Seal Beach $\left(708 \mathrm{~kg} / \mathrm{m}^{3} ; n=4\right.$; Brown, unpublished data, 2014) with our mean total flux value $\left(F_{g / s}\right)$ to calculate $M A_{p}$ using the following equation:

$M A_{p}=\left[D A^{-1}\right] \times\left[F_{(g / s)}\right] \times\left[B D^{-1}\right] \times\left[3.1536 \times 10^{7}\right]$

Next, we calculated the total flux ( $\mathrm{kg} /$ year) needed to keep pace with several local rates of SLR (mm/year; http://www. tidesandcurrents.noaa.gov/sltrends/sltrends.shtml), using the same equation as above, and, after substituting SLR for PMA, we solved for $F_{s l r}$ using the following equation:

$F_{s l r}=[D A] \times[S L R] \times[B D] /[1000]$

Finally, we estimated a mineral accretion deficit $\left(M A_{d}\right)$, which is likely a conservative measure of accretion because it omits organic accretion via plant growth, using the following equation:

$$
M A_{d}=\left[F_{s l r}\right]-\left[F_{(k g / y r)}\right]
$$

\section{Suspended Sediment Concentration and Vertical Accretion on the Salt Marsh Plain}

We monitored suspended sediment concentration on the salt marsh plain at both sites from 11 January to 3 March 2014 using 30 0.25-L, single-stage, siphon samplers (Inter-Agency Committee on Water Resources Subcommittee On Sedimentation 1961) which were deployed opportunistically (when the tide was expected to fill most of the samplers) prior to and sampled on flood tides in transects at distances $0,1,2$, $3,5,8,10,15,22$, and $31 \mathrm{~m}$ perpendicular to the edge of tidal creek. With intake heights of $7 \mathrm{~cm}$, samplers filled rapidly and measured suspended sediment concentration representing an instantaneous value. Lab methods followed protocols detailed 
by the US Environmental Protection Agency (1971). Blank glass fiber filters were washed with distilled water, dried for $1 \mathrm{~h}$ at $103-105^{\circ} \mathrm{C}$, and then cooled in a desiccator. The entire water sample was passed through the clean pre-weighed filter using a vacuum hose filtration setup. Samples were dried at $103-105^{\circ} \mathrm{C}$ for $1 \mathrm{~h}$, cooled in a desiccator, and weighed to the nearest milligram to determine dry weight of sediment (DW). Samples again were dried at $103-105{ }^{\circ} \mathrm{C}$ for another 20 $30 \mathrm{~min}$, cooled in a desiccator, and reweighed to confirm that no additional mass loss had occurred. Glass fiber filters were combusted in crucibles in a muffle furnace at $550{ }^{\circ} \mathrm{C}$ for at least $10 \mathrm{~h}$ to determine loss on ignition (LOI; $\mathrm{mg}$ ) and, thus, percent mineral content ( $\mathrm{M}_{\%}$ ) (US Environmental Protection Agency 1993), where:

$M_{\%}=\left[([D W]-[L O I]) \times\left[D W^{-1}\right]\right] \times 100$

For the calculation of surface suspended sediment concentrations and percent mineral content, we reclassified distances as in channel $(0 \mathrm{~m})$, near $(1-3 \mathrm{~m})$, mid $(5-10 \mathrm{~m})$, and far (15-31 m).

Marker horizons (Cahoon and Turner 1989) were established at near (3 m), mid (10 m), and far (30 m) locations adjacent to surface suspended sediment concentration sampling sites; these were only sampled at Mugu following the storm due to access restrictions at Seal Beach. Dry Custer Feldspar clay $(1200-1600 \mathrm{~mL})$ was sprinkled within the perimeter of a $0.5 \mathrm{~m} \times 0.5 \mathrm{~m}$ quadrat, and the vegetation was shaken thoroughly to settle the feldspar. Corners of the plots were marked with a gray polyvinyl chloride pipe. In September, we used a plug extraction method suitable for drier soils (Cahoon et al. 1996). The sampling method consisted of visually surveying the plot to see if any feldspar was exposed. If feldspar was visible in any area of the plot, we recorded accretion as zero. However, if the plot was covered by sediment, we carefully extracted an approximately $3 \times 3 \times 6 \mathrm{~cm}$ plug with a serrated kitchen knife, measuring the newly formed representative sediment layer on three or four sides of the plug with a ruler or calipers to the nearest millimeter. These three or four measurements were averaged to give the accretion value of each plot.

\section{Surface Elevation Change}

On the marsh plain at Mugu and Seal Beach, fine-scale surface elevation changes $(\mathrm{mm})$ were measured using surface elevation tables (SETs) (Cahoon et al. 2002). Four SETs were established at each study site, with two in high and two in low marsh vegetation zones. Each SET consisted of 36 measurements where nine pins were positioned in four directions to measure elevations on the surface of the marsh. SETs at Seal Beach were first measured on 6 December 2013, while SETs at Mugu were first measured on 27 April 2013. Final measurements were taken on 20 February 2015 at Mugu and 28 February 2015 at Seal Beach.

\section{Meteorological Data}

Hourly measurements of precipitation for Seal Beach were retrieved from CIMIS no. 174 (http://www.ipm.ucdavis. edu/) which is $7 \mathrm{~km}$ north of the site. Hourly measurements of barometric pressure for Seal Beach were obtained from 9410660-Los Angeles (http://www.ndbc.noaa.gov/), approximately $17 \mathrm{~km}$ west. Hourly measurements of wind speed and wind direction were obtained from buoy location 9410665-Los Angeles Pier J (http://www.ndbc.noaa.gov/), which is $9.8 \mathrm{~km}$ west of the site. Hourly measurements of precipitation for Mugu were retrieved from CIMIS no. 156 (http://www.ipm.ucdavis.edu/), located approximately $17 \mathrm{~km}$ northwest. Hourly measurements of barometric pressure, wind speed, and direction for Mugu were obtained from nearest buoy location with relevant data, 46025-Santa Monica Basin (http://www.ndbc.noaa.gov/), 40 km south.

\section{Error Assessment}

Because random and independent errors occur during velocity measurement, calibration, and laboratory measurement of suspended sediment concentration, a conservative estimate of $27 \%$ random error, originally calculated by Ganju et al. (2005) for Brown's Island in the San Francisco Bay Area, was applied to net flux estimates for Seal Beach1 and Seal Beach2. In that study, Ganju et al. (2005) analyzed all measurements for their contribution to total error in the flux calculation and thus unmeasured exports and imports. Furthermore, because errors can be magnified between calculated parabolic area and a measured cross-section, we calculated the resultant error that could arise in the mean total flux for Mugu1. Then, we combined the two sources of error to obtain a cumulative estimate of random error that was applied to our net flux estimates at Mugu1.

\section{Results}

\section{Seal Beach National Wildlife Refuge}

\section{Continuous Tidal Water Channel Fluxes and Suspended Sediment Concentration}

Tide range for Seal Beach1 was approximately $2 \mathrm{~m}$ (Fig. 4), and maximum instantaneous flood and ebb velocities were 0.66 and $0.61 \mathrm{~m} / \mathrm{s}$. Peak instantaneous water fluxes during flood and ebb periods were 47 and $34 \mathrm{~m}^{3} / \mathrm{s}$ (Fig. 4). All maximum velocities and fluxes occurred 
Fig. 4 Time series of wind speed and direction, water level, tidal water flux, suspended sediment concentration, and suspended sediment flux at Seal Beach1. The black line in top graph is scaled to right. In the wind vector plot, lines point to direction where wind is going. In the bottom four graphs, grey lines represent instantaneous values, while all smoothed black lines represent low-pass-filtered values; positive values indicate sediment import. Low-passfiltered water level represents root-mean-squared value. Shaded bar indicates timing of storm event in late February to early March
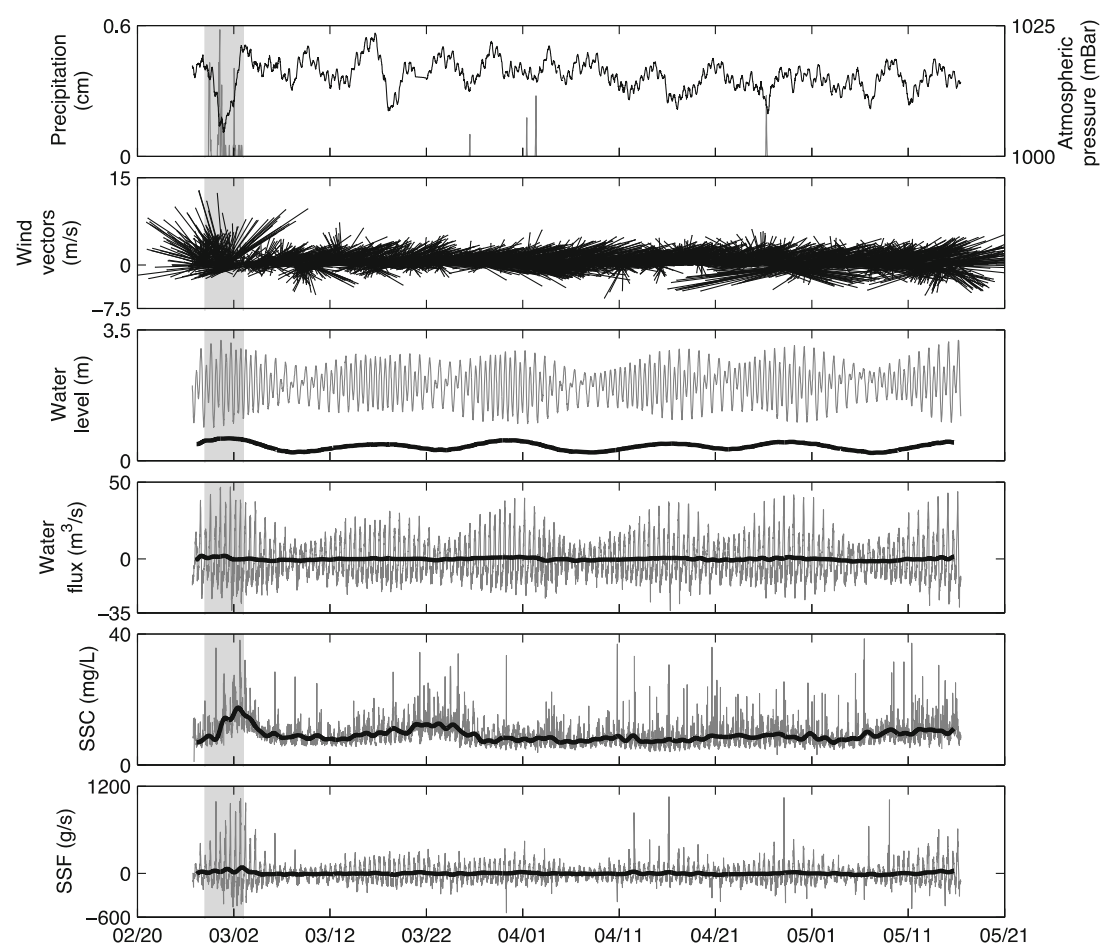

during a storm from 27 February to 2 March 2014 (herein referred to as "the storm"), which coincided with a lowpressure event characterized by a pressure drop to 1004 mbar, precipitation of $4.7 \mathrm{~cm}$, and strong winds that peaked at $14 \mathrm{~m} / \mathrm{s}$ from the southeast (Figs. 4 and 5). During the storm, mean instantaneous suspended sediment concentration increased to $13 \mathrm{mg} / \mathrm{L}$ at Seal Beach1, compared to mean instantaneous suspended sediment concentration of $9 \mathrm{mg} / \mathrm{L}$ for the remaining study period. For the entire study period, maximum instantaneous ebb (39 $\mathrm{mg} / \mathrm{L})$ and flood $(38 \mathrm{mg} / \mathrm{L})$ suspended sediment concentrations, as well as mean instantaneous ebb $(9 \mathrm{mg} / \mathrm{L})$ and mean instantaneous flood $(9 \mathrm{mg} / \mathrm{L})$ suspended sediment concentrations, were balanced.
Fig. 5 Time series of wind speed and direction, water level, tidal water flux, suspended sediment concentration, and suspended sediment flux at Seal Beach2. Black line in top graph is scaled to right. In wind vector plot, lines point to direction where wind is going. In the bottom four graphs, grey lines represent instantaneous values, while all smoothed black lines represent low-pass-filtered values; positive values indicate sediment import. Low-passfiltered water level represents root-mean-squared value. Shaded bar indicates timing of storm event in late February to early March

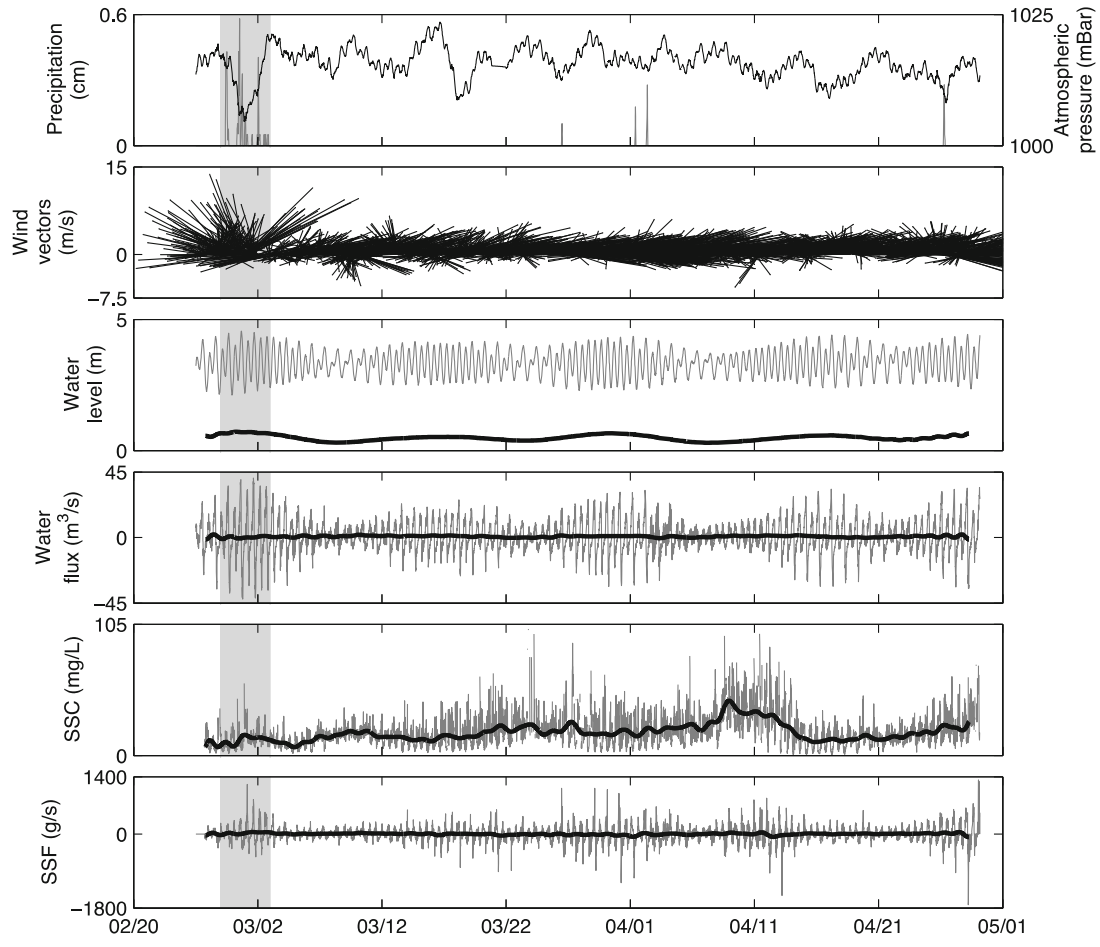


As expected, given the small size of the site, maximum tide range for Seal Beach2 was approximately $2 \mathrm{~m}$ (Fig. 5). Maximum instantaneous flood and ebb velocities were 0.29 and $0.35 \mathrm{~m} / \mathrm{s}$. Peak instantaneous tidal water fluxes during flood and ebb periods were 41 and $42 \mathrm{~m}^{3} / \mathrm{s}$ (Fig. 5). During the storm, mean instantaneous suspended sediment concentration decreased to $13 \mathrm{mg} / \mathrm{L}$, compared to mean instantaneous suspended sediment concentration of $19 \mathrm{mg} / \mathrm{L}$ for the entire study period. Similar to Seal Beach1, maximum instantaneous ebb $(97 \mathrm{mg} / \mathrm{L})$ and flood $(101 \mathrm{mg} / \mathrm{L})$ suspended sediment concentration values, as well as mean instantaneous ebb $(20 \mathrm{mg} / \mathrm{L})$ and mean instantaneous flood $(18 \mathrm{mg} / \mathrm{L})$ suspended sediment concentration values, were balanced.

\section{Sediment Flux Decomposition}

Mean total sediment flux was lowest at Seal Beach1, with a mean import rate of $0.50 \mathrm{~g} / \mathrm{s}$ (Table 1). Over the entire period, a large, landward Stokes drift compensated the advective flux component; dispersive flux was negligible. During the storm, mean total flux increased to $39 \mathrm{~g} / \mathrm{s}$ landward, mainly due to an increase in dispersive flux ( $23 \mathrm{~g} / \mathrm{s})$, although all flux components increased in magnitude during the storm (Table 2). Landward fluxes correspond with higher mean suspended sediment concentration and instantaneous water fluxes during the storm (Fig. 4). After normalizing for channel area, mean total flux during that period was $0.71 \mathrm{~g} / \mathrm{m}^{2} / \mathrm{s}$ in the landward direction (Table 2). During the storm, winds from the southeast and southwest were strongest, with mean wind speed of $5.6 \mathrm{~m} / \mathrm{s}$. Mean total flux during $10 \mathrm{~m} / \mathrm{s}$ or greater wind events from the south direction was $5.2 \mathrm{~g} / \mathrm{s}$ in the landward direction; however, during non-storm periods, mean total flux was $24 \mathrm{~g} /$ $\mathrm{s}$ and landward when wind speeds reached $10 \mathrm{~m} / \mathrm{s}$ or greater.

Net sediment flux was greater at Seal Beach2 with a mean import rate of $4.9 \mathrm{~g} / \mathrm{s}$ (Table 1). Stokes drift was the largest component in the landward direction, while dispersive flux was smaller but seaward. In contrast to Seal Beach1, advective flux was the weakest component and was in the landward direction. During the storm, mean total flux increased to $28 \mathrm{~g} / \mathrm{s}$, mainly due to an increase in dispersive flux $(21 \mathrm{~g} / \mathrm{s})$, although all flux components increased in magnitude during the storm (Table 2). The directions of all flux components during the storm match those of Seal Beach1. After normalizing for channel area, mean total flux during that period was $0.29 \mathrm{~g} / \mathrm{m}^{2} / \mathrm{s}$ in the landward direction (Table 2). Although mean suspended sediment concentration was lower during the storm, landward sediment fluxes arose from increased instantaneous landward water fluxes during the storm (Fig. 5). Mean total flux during $10 \mathrm{~m} / \mathrm{s}$ or greater wind events was $42 \mathrm{~g} /$ $\mathrm{s}$ in the seaward direction; however, during non-storm periods, mean total flux was $3.0 \mathrm{~g} / \mathrm{s}$ and landward when wind speeds reached $10 \mathrm{~m} / \mathrm{s}$ or greater.

\section{Central Basin of Mugu Lagoon}

\section{Continuous Tidal Water Fluxes and Suspended Sediment Concentration}

Tide range for Mugu was approximately $2 \mathrm{~m}$. (Fig. 6). Maximum instantaneous flood and ebb velocities were 0.84 and $0.66 \mathrm{~m} / \mathrm{s}$ (Fig. 6). This particular flood velocity peak occurred during a 4-day, exceptionally high tide event between 21 June 2013 and 24 June 2013 (herein referred to as "the exceptionally high tide"). With the highest tides of the study period occurring on 23 and 24 June, increased velocity coincided with a peak in suspended sediment concentration at $79 \mathrm{mg} / \mathrm{L}$, which was also the highest for the entire study period. Mean suspended sediment concentration increased to $23 \mathrm{mg} / \mathrm{L}$, compared to mean flood and ebb suspended sediment concentration of $13 \mathrm{mg} / \mathrm{L}$ for the remainder of the study period.

\section{Sediment Flux Decomposition}

Net sediment flux was landward at a rate of $1.1 \mathrm{~g} / \mathrm{s}$ at Mugu1 (Table 1). Sediment flux components at Mugu1 were all landward, ranging between 0.07 and $0.77 \mathrm{~g} / \mathrm{s}$. During the exceptionally high tide, mean total flux increased to $4.4 \mathrm{~g} / \mathrm{s}$, mainly due to an increase in mean advective flux $(3.7 \mathrm{~g} / \mathrm{s})$. Landward fluxes correspond with higher mean suspended sediment
Table 1 Sediment flux composition at Mugu and Seal Beach

\begin{tabular}{llll}
\hline Parameter & Site & & \\
\hline Sediment flux component & Mugu1 & Seal Beach1 & Seal Beach2 \\
Mean advective $(\langle u>\langle a\rangle\langle c\rangle)$ & $0.77 \mathrm{~g} / \mathrm{s}$ & $-11 \mathrm{~g} / \mathrm{s}$ & $4.2 \mathrm{~g} / \mathrm{s}$ \\
Mean dispersive $\left(\left\langle u^{\prime}\right\rangle\left\langle a><c^{\prime}\right\rangle\right)$ & $0.30 \mathrm{~g} / \mathrm{s}$ & $1.4 \mathrm{~g} / \mathrm{s}$ & $-6.4 \mathrm{~g} / \mathrm{s}$ \\
Mean stokes drift $\left(u^{\prime} a^{\prime}<c>\right)$ & $0.071 \mathrm{~g} / \mathrm{s}$ & $10 \mathrm{~g} / \mathrm{s}$ & $8.5 \mathrm{~g} / \mathrm{s}$ \\
Mean total flux & $1.1 \pm 1.2 \mathrm{~g} / \mathrm{s}$ & $0.50 \pm 0.14 \mathrm{~g} / \mathrm{s}$ & $4.9 \pm 1.3 \mathrm{~g} / \mathrm{s}$ \\
Mean total flux normalized by channel area & $0.56 \mathrm{~g} / \mathrm{m}^{2} / \mathrm{s}$ & $0.0091 \mathrm{~g} / \mathrm{m}^{2} / \mathrm{s}$ & $0.052 \mathrm{~g} / \mathrm{m}^{2} / \mathrm{s}$ \\
Calculated potential accretion & $0.23 \mathrm{~mm} /$ year & $0.047 \mathrm{~mm} / \mathrm{year}$ & $0.32 \mathrm{~mm} / \mathrm{year}$ \\
\hline
\end{tabular}

Positive values indicate sediment import. Error bars indicate a $110 \%$ (Mugu1) and $27 \%$ (Seal Beach1 and Seal Beach2) random error estimate 
Table 2 Sediment flux components during multi-day storm event in 2014, compared to non-storm periods and entire study period (total)

\begin{tabular}{|c|c|c|c|c|c|c|}
\hline \multirow{2}{*}{$\begin{array}{l}\text { Parameter } \\
\text { Sediment flux component }(\mathrm{g} / \mathrm{s})\end{array}$} & \multicolumn{3}{|c|}{ Seal Beach1 } & \multicolumn{3}{|c|}{ Seal Beach2 } \\
\hline & Storm & Non-storm & Total & Storm & Non-storm & Total \\
\hline Mean advective $(<u><a><c>)(\mathrm{g} / \mathrm{s})$ & -17 & -11 & -11 & -8.5 & 4.9 & 4.2 \\
\hline Mean dispersive $\left(<u^{\prime}><a><c^{\prime}>\right)(\mathrm{g} / \mathrm{s})$ & 23 & 0.39 & 1.4 & 21 & -8.0 & -6.4 \\
\hline Mean stokes drift $\left(u^{\prime} a^{\prime}<c>\right)(\mathrm{g} / \mathrm{s})$ & 26 & 9.3 & 10 & 11 & 8.4 & 8.5 \\
\hline Mean total flux $(\mathrm{g} / \mathrm{s})$ & 39 & -1.3 & 0.50 & 28 & -3.5 & 4.9 \\
\hline Mean total flux normalized by channel area $\left(\mathrm{g} / \mathrm{m}^{2} / \mathrm{s}\right)$ & 0.71 & -0.024 & 0.0091 & 0.29 & 0.037 & 0.052 \\
\hline Advective $(<u><a><c>)(\mathrm{kg})$ & -5400 & $-73,000$ & $-78,000$ & -2600 & 25,000 & 23,000 \\
\hline Dispersive $\left(<u^{\prime}><a><c^{\prime}>\right)(\mathrm{kg})$ & 7100 & 2600 & 9800 & 6500 & $-41,000$ & $-35,000$ \\
\hline Stokes drift $\left(u^{\prime} a^{\prime}<c>\right)(\mathrm{kg})$ & 7900 & 61,000 & 69,000 & 3400 & 43,000 & 46,000 \\
\hline Total flux $(\mathrm{kg})$ & 12,000 & -8700 & 3400 & 8800 & 18,000 & 27,000 \\
\hline
\end{tabular}

concentration and water levels during the exceptionally high tides (Fig. 6). Total flux normalized by channel area was $1.5 \mathrm{~g} /$ $\mathrm{m}^{2} / \mathrm{s}$ during this exceptionally high tide sequence.

\section{Patterns of Sediment Flux and Tidal Energy}

At Mugu1, the daily average of root-mean-square (RMS) tidal velocity was correlated with the daily average of total flux ( $n=$ $83, r^{2}=0.54, \mathrm{rms}=1.2$; Fig. 7). While there was also a strong relationship between tidal energy and total flux at Seal Beach1 $\left(n=79, r^{2}=0.54\right.$, rms $=9.0$; Fig. 7), daily average of RMS velocity and daily average of total sediment flux were weakly correlated at Seal Beach2 $\left(n=62, r^{2}=0.01, \mathrm{rms}=17\right.$; Fig. 7).

\section{Error Assessment}

Based on the results from a comprehensive assessment of random errors in similar studies by Ganju et al. (2005;
2013), a conservative estimate of $27 \%$ random error for Seal Beach1 and Seal Beach2 was applied to our net flux estimates $( \pm 0.14 \mathrm{~g} / \mathrm{s}$ and $\pm 1.3 \mathrm{~g} / \mathrm{s}$ at Seal Beach 1 and Seal Beach2, respectively; Table 1). Furthermore, we found that our assumption of parabolic area for Mugu1 was not a large additional source of error. We compared the total flux calculation between measured and parabolic areas at Seal Beach1 and Seal Beach 2 and found that the largest source of error was using $u$ instead of $v_{c a}$. In Mugu1, where we used $u$, the channel is much narrower and therefore $u$ is likely closer to $v_{c a}$ than it is at Seal Beach1. When we tested this assumption at Seal Beach1 and Seal Beach2, the errors were 0.30 and $82 \%$. Therefore, a combined conservative estimate of $110 \%$ random error was applied to our net flux estimates at Mugul $( \pm 1.2 \mathrm{~g} / \mathrm{s}$; Table 1). Even with these errors, the net fluxes at all sites are balanced (i.e., close to zero) and still substantially smaller than recently studied systems, which employed the same methods (e.g., Ganju et al. 2013).
Fig. 6 Time series of wind speed and direction, water level, tidal water flux, suspended sediment concentration, and suspended sediment flux at Mugu1. In wind vector plot, lines point to direction where wind is going. In the bottom three graphs, grey lines represent instantaneous values, while all smoothed black lines represent low-pass-filtered values; positive values indicate sediment import. Low-passfiltered water level represents root-mean-squared value. Shaded bar indicates timing of exceptionally high tide event in June

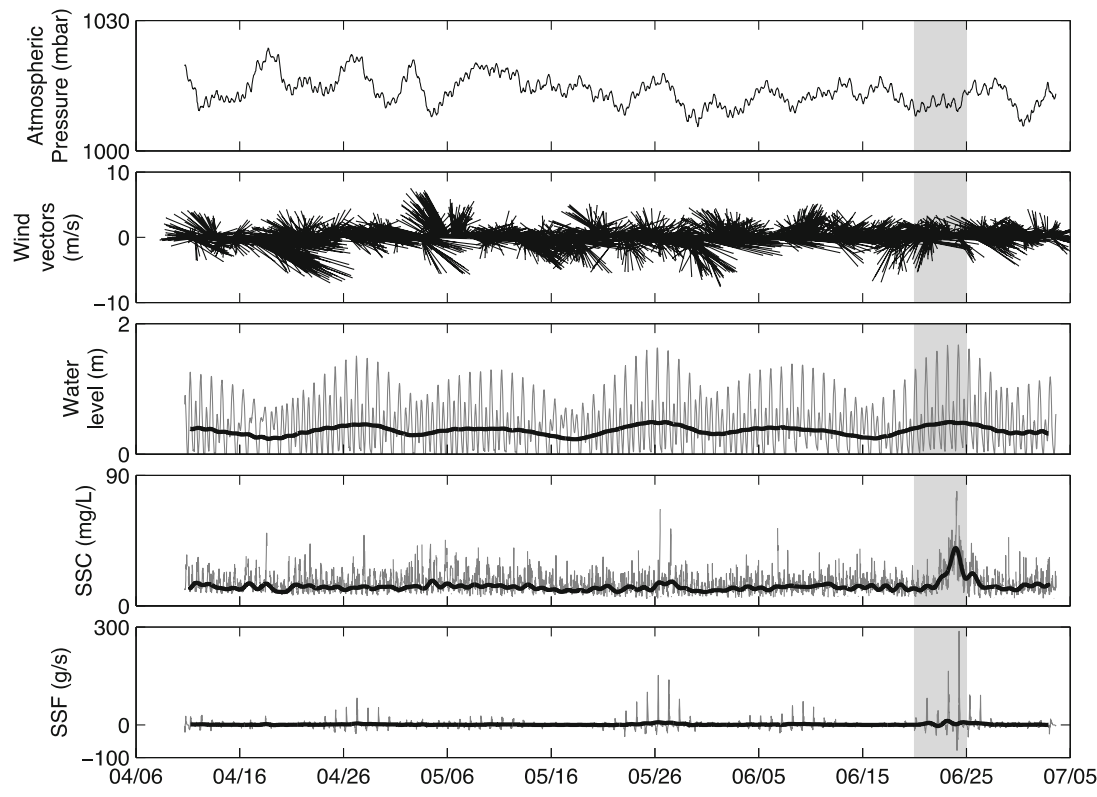



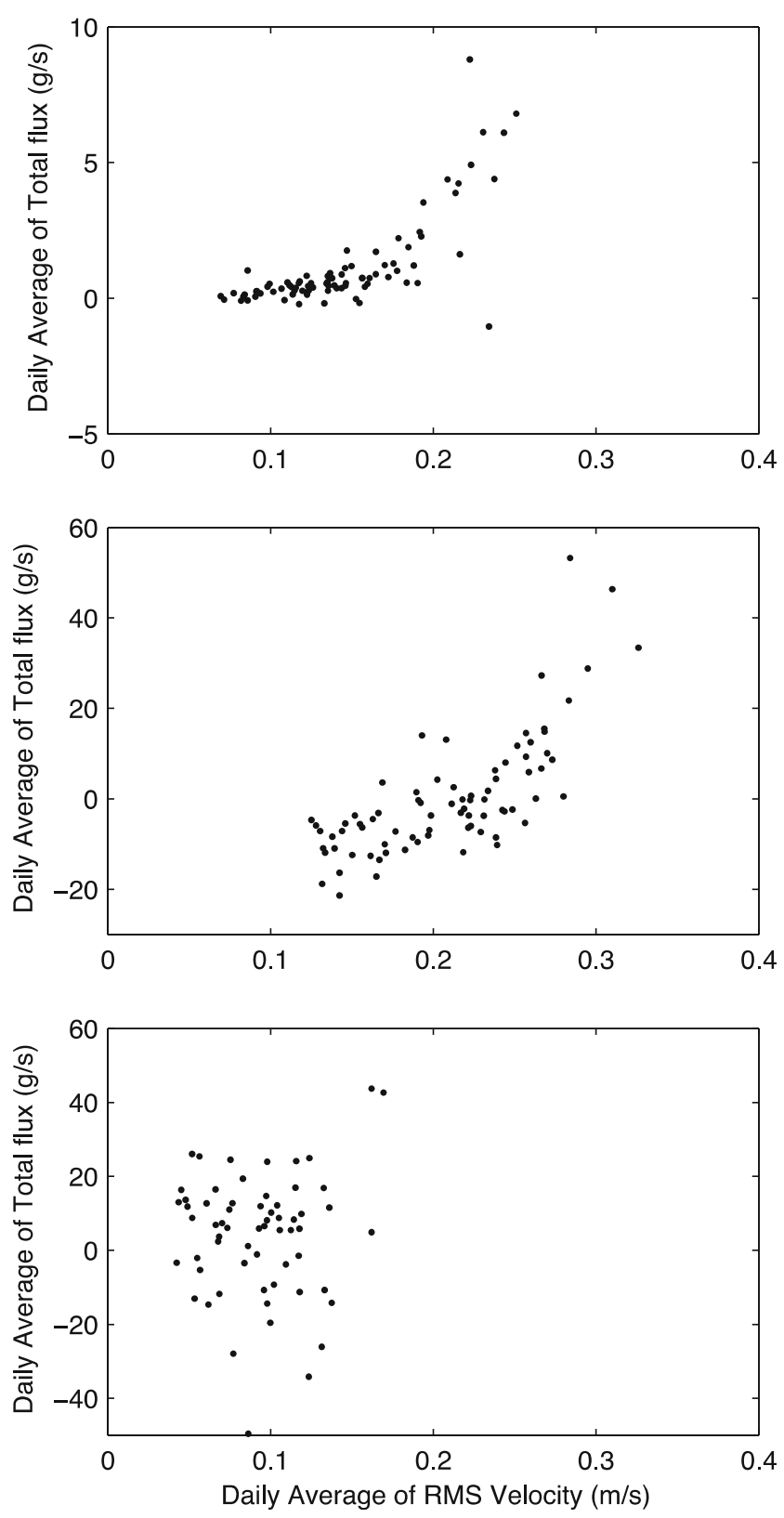

Fig. 7 Relationship between daily average of root-mean-squared (RMS) tidal velocity $(\mathrm{m} / \mathrm{s})$ and daily average of total flux $(\mathrm{g} / \mathrm{s})$ at sites Mugu1 (top), Seal Beach1 (center), and Seal Beach2 (bottom); Positive flux indicates sediment import

\section{Suspended Sediment Concentration and Vertical Accretion on the Salt Marsh Plain}

Using siphon samplers during the storm that impacted fluxes at Seal Beach1 and Seal Beach2 between 27 February and 2 March 2014, we measured instantaneous suspended sediment concentration in the tidal creek and within $15 \mathrm{~m}$ of the edge was four times greater than suspended sediment concentration values measured during dry weather (January-February 2014) at both Seal Beach and Mugu (Table 3). This coincided with peak discharges of 82 and $75 \mathrm{~m}^{3} / \mathrm{s}$ in Calleguas Creek on 28 February and 1 March 2014, respectively (http:// waterdata.usgs.gov/nwis). During the storm, mean suspended sediment concentration measured in the tidal creeks and salt marsh plain of Mugu surpassed the peak suspended sediment concentration values recorded by all YSIs. Mean percent mineral content in suspended sediment concentration storm samples from Mugu and Seal Beach during dry weather was $85 \%$, while mean percent mineral content was $76 \%$ for Mugu. Also, patterns of suspended sediment concentrations on the marsh plain showed declines of $24 \%$ at Mugu during the storm, $31 \%$ at Mugu during dry weather, and $30 \%$ at Seal Beach during dry weather from the tidal creek to near creek stations (Table 3). Consequently, 1-2 mm of sediment settled on the marsh plain at Mugu mostly concentrated within $10 \mathrm{~m}$ of the tidal creek edge (Fig. 8).

\section{Surface Elevation Change}

Cumulative surface elevation change at Seal Beach over 449 days, which included effects of above- and belowground processes, was $-1.6 \pm 8.9 \mathrm{~mm} /$ year (mean $\pm \mathrm{SE} ; n=4$ ). In the high marsh SETs $(n=2)$, cumulative surface elevation change was $-2.1 \pm 15 \mathrm{~mm} /$ year (mean $\pm \mathrm{SE}$ ), while the low marsh SETs $(n=2)$ had less variability with cumulative surface elevation change of $-1.2 \pm 0.72 \mathrm{~mm} /$ year (mean $\pm \mathrm{SE}$ ).

Over a span of 664 days, the cumulative surface elevation change for Mugu was $0.37 \pm 0.69 \mathrm{~mm} /$ year (mean $\pm \mathrm{SE} ; n=4$ ). In the high marsh SETs $(n=2)$, cumulative surface elevation change was $-0.81 \pm 0.26 \mathrm{~mm} /$ year (mean $\pm \mathrm{SE}$ ), while the low marsh SETs $(n=2)$ had cumulative surface elevation change of $1.6 \pm 1.1 \mathrm{~mm} /$ year $($ mean $\pm \mathrm{SE})$.

\section{Discussion}

\section{Atmospheric and Tidal Controls on Sediment Transport}

We found that during low precipitation and dry periods on the southern California coast, sediment fluxes were balanced and a non-El Niño winter storm and exceptionally high tide accounted for the majority of sediment import to these marshes. For example, at Seal Beach1, over 12, $000 \mathrm{~kg}$ of sediment input during the storm offsets the 75 -day dry weather seaward flux of over $8700 \mathrm{~kg}$ (Table 2). The storm event-amplified landward dispersive fluxes in both channels were likely related to increased storm surges that also yielded $33 \%$ of the sediment import for Seal Beach2 during the period of record. During the storm, peak suspended sediment concentration occurred at high tide, which indicated that tidal transport is driving the flux from a seaward source via the low marsh 
Table 3 Average suspended sediment concentration values on marsh surface and in tidal creeks measured in 2014

\begin{tabular}{llll}
\hline Metric & Site & \\
\hline Distance from tidal creek edge & Mugu (storm) & Mugu (no storm) & Seal Beach (no storm) \\
Tidal creek & $264 \pm 61 \mathrm{mg} / \mathrm{L}(n=12)$ & $51 \pm 5 \mathrm{mg} / \mathrm{L}(n=12)$ & $58 \pm 7 \mathrm{mg} / \mathrm{L}(n=27)$ \\
Near $(1-3 \mathrm{~m})$ & $202 \pm 27 \mathrm{mg} / \mathrm{L}(n=23)$ & $34 \pm 3 \mathrm{mg} / \mathrm{L}(n=36)$ & $40 \pm 2 \mathrm{mg} / \mathrm{L}(n=70)$ \\
Mid $(5-10 \mathrm{~m})$ & $214 \pm 30 \mathrm{mg} / \mathrm{L}(n=33)$ & $37 \pm 4 \mathrm{mg} / \mathrm{L}(n=36)$ & $39 \pm 1 \mathrm{mg} / \mathrm{L}(n=72)$ \\
Far $(15-31 \mathrm{~m})$ & $77 \pm 9 \mathrm{mg} / \mathrm{L}(n=31)$ & $31 \pm 4 \mathrm{mg} / \mathrm{L}(n=36)$ & $35 \pm 1 \mathrm{mg} / \mathrm{L}(n=79)$ \\
\hline
\end{tabular}

Error bars indicate a range of \pm 1 standard error at Seal Beach or Anaheim Bay. In addition, total fluxes $(1700 \mathrm{~kg})$ at Mugu during the exceptionally high tide accounted for $20 \%$ of the net flux for the entire 84-day study period.

Sediment fluxes we observed were small compared to other salt marshes, especially those that are subject to a greater frequency of storms such as the Atlantic coast of North America (Ganju et al. 2013). Episodic import of sediment during more powerful storms has been documented in marshes with less urbanized basins; for example, open water areas near Mugu and Tijuana Estuary have been partially filled by intense, isolated storms during El Niño events (Onuf 1987; Cahoon et al. 1996). Warrick and Farnsworth (2009b) found that most sediment transport occurred during El Niño or at intervals greater than 10 years. In the mid-Atlantic, the Blackwater National Wildlife Refuge complex was found to export over $1000 \mathrm{~g} / \mathrm{s}$ or $5.9 \mathrm{~g} / \mathrm{m}^{2} /$ year, while the proximal Transquaking complex was found to import over $31 \mathrm{~g} / \mathrm{s}$ or $7.0 \mathrm{~g} / \mathrm{m}^{2} /$ year over similar time scales (Ganju et al. 2013). In these highly dynamic estuaries of the east coast, meteorological forcing events led to export of sediments, while seaward sources of sediment contribute to stability via dispersive landward flux. Gardner and Kjerfve (2006) also observed larger inorganic sediment fluxes in salt marshes of $18 \mathrm{~g} / \mathrm{m}^{2} /$ year for Crab Haul Creek and $1480 \mathrm{~g} / \mathrm{m}^{2} /$ year at Bly Creek, South Carolina, during a 1-year study. In Atlantic coast marshes, a larger magnitude in fluxes may be due to increased frequency and intensity of large storms resulting in storm surges, which facilitate sediment deposition (Fagherazzi et al. 2013b).

Still, while long-term fluxes may appear large in magnitude due to isolated storm events, tidal driven fluxes are often balanced in the short term. French et al. (2008) observed balanced sediment fluxes in the United Kingdom that were characterized by nearly equivalent flood tide and ebb tide suspended sediment concentration values with a small import during tide-dominated periods; however, resuspension from westerly winds $(>10 \mathrm{~m} / \mathrm{s})$ disrupted this balance by exporting sediment from the system. With the exception of the storm period, when winds exceeded $10 \mathrm{~m} / \mathrm{s}$ at Seal Beach1, Seal Beach2, and Mugu1, landward mean total fluxes were 3.0, 2.5 , and $24 \mathrm{~g} / \mathrm{s}$, respectively. These values suggested that wind alone is not going to alter the magnitude of the fluxes, in contrast to the previous study.

Our study captured one storm and one exceptionally high tide to illustrate a short-term period of sediment flux balanced exchange, because Seal Beach1, Seal Beach2, and Mugu1
Fig. 8 Photo of accretion measured on marker horizons landward of site Mugu1, measured after a storm that occurred between 27 February and 2 March at Mugu

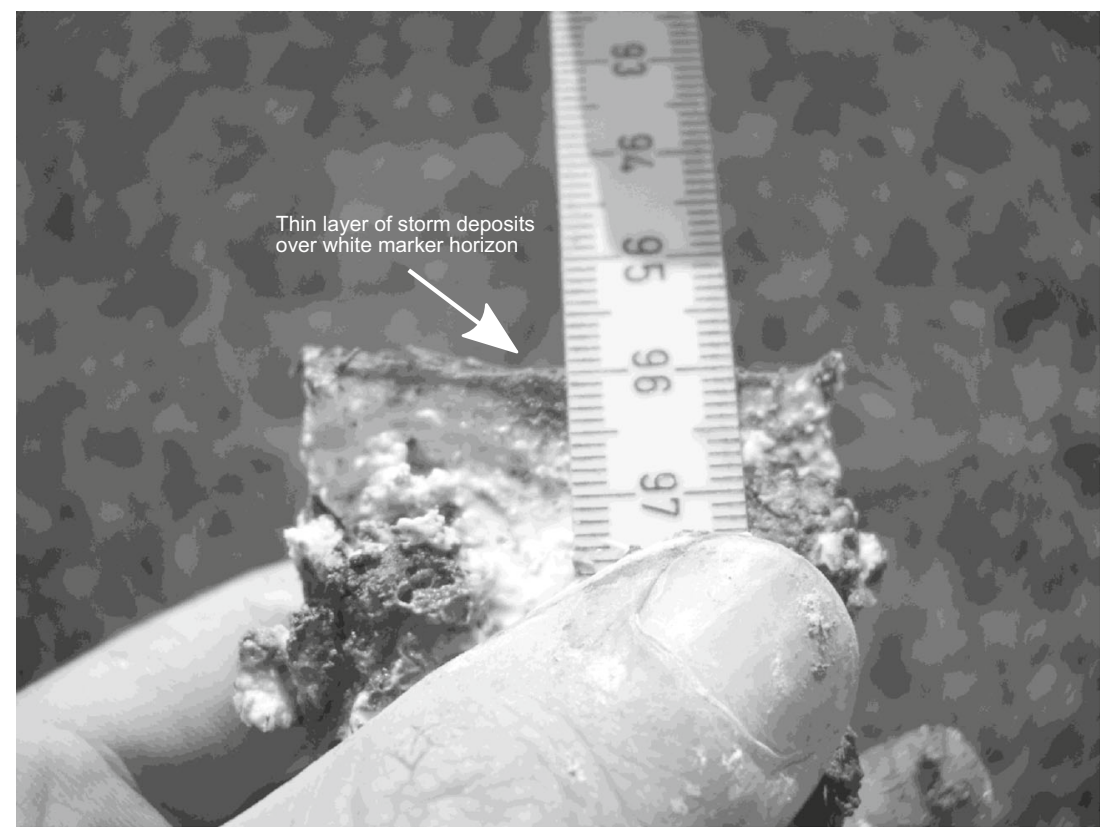


essentially had equivalent mean instantaneous flood and ebb suspended sediment concentration. Tidal energy appeared to be driving the magnitude of the flux within the tidal channels in these salt marshes. In other marshes, storm-driven surge has accounted for a large percent of sediment fluxes over time (Cahoon et al. 1996; Turner et al. 2006; Fagherazzi et al. 2013b). However, not all of our sites responded to tidal energy; the discrepancy is likely a result of the lower range of velocities observed in Seal Beach2. Further study is needed to confirm whether tidal energy is driving landward sediment fluxes during exceptionally high tides and during a larger range of tidal velocities at other southern California marshes. The results from our study suggest that infrequent storms and exceptionally high tides may play a large role in importing sediment and maintaining sediment flux balance for southern California salt marshes in basins with different landscape developments and modifications.

\section{Future Stability of Southern California Marshes in the Face of SLR}

In the face of SLR, a balanced sediment budget during dry periods does not indicate stability as the geomorphic platform of marsh, intertidal flat, and tidal channel require sediment import to maintain configuration and marsh elevations (Fagherazzi et al. 2013a). While organic accretion can mitigate the lack of mineral accretion during times of low SLR (Morris et al. 2002), mineral sediment accretion is a key component of resilience (Callaway et al. 1997). Research in salt marshes in the Dutch Wadden Sea suggests that SLR creates additional demand for sediment as the rate of accretion and surface elevation needs to increase (Van Wijnen and Bakker 2001). Because our data focused on fluxes during a drought, inferences about stability may only apply to other dry periods, but these dry weather conditions are characteristic of the southern California climate.

Following the methodology of Ganju et al. (2013), we assessed stability based on current regional SLR rates. From Santa Barbara to Newport Beach (the closest monitoring stations to our study sites), local rates of relative SLR are variable (ranging from 0.32 to $3.2 \mathrm{~mm} /$ year; http://tidesandcurrents. noaa.gov/sltrends/sltrends.html). By combining our sediment flux measurements with estimated salt marsh DA of $0.48,0$. 69, and $0.25 \mathrm{~km}^{2}$ for Seal Beach1, Seal Beach2, and Mugu1, respectively, and measured soil BD 708 and $630 \mathrm{~kg} / \mathrm{m}^{3}$ for Seal Beach and Mugu (Brown, unpublished data, 2014; Elgin and Ambrose, unpublished data, 2012), we calculated potential mineral accretion rates of $0.047,0.32$, and 0 . $23 \mathrm{~mm} /$ year for Seal Beach1, Seal Beach2, and Mugu2, respectively (Table 1).

The low accretion rate at Mugu is supported by previous short-term observations of no net accretion during dry periods (Rosencranz, unpublished data, 2012). At Mugu over longer time scales, combined impacts of infrequent storms and organic accretion yielded a slightly higher rate of 1-2 mm/year between 1995 and 2009 (Chan and Ambrose, unpublished, 2010). While likely site-specific and not necessarily applicable to Mugu and/or Seal Beach, in cordgrass-dominated portions of Tijuana Estuary, Cahoon et al. (1996) found higher rates of accretion compared to pickleweed-dominated portions which are likely related to an increase in inundation frequency and duration in lower elevations. In comparison to the relatively low rate of SLR in Los Angeles ( $0.82 \mathrm{~mm} /$ year), Seal Beach1 and Seal Beach2, with an annual dry period net flux of 16,000 and $150,000 \mathrm{~kg} /$ year, would have deficits of 260,000 and $250,000 \mathrm{~kg} / \mathrm{year}$, based on their current rate of dry period import. Conversely, Seal Beach1 and Seal Beach2 would both run annual deficits of 730,000 and 930,000 kg of sediment based on the Newport Beach's $2.2 \mathrm{~mm} /$ year local rate of SLR.

A comparison of the dry weather net flux at Mugul to three local rates of SLR from Santa Monica (1.4 mm/year), Rincon Island ( $3.2 \mathrm{~mm} / \mathrm{year})$, and Santa Barbara $(0.32 \mathrm{~mm} / \mathrm{year})$ yielded mineral deficits of $460,000,180,000$, and $14,000 \mathrm{~kg}$. Extrapolation from the brief study periods is justified considering we sampled during a dry period, which is representative of the region's dominant climate pattern increasing under future projections. However, these mineral elevation deficits are likely conservative, considering some of the sediment within the tidal creek is not expected to reach the marsh plain, and this notion is supported by a $30 \%$ decline in suspended sediment concentration from tidal creek to the interior from our study.

Moskalski and Sommerfield (2012) observed a similar decline in suspended sediment concentration from tidal creek to the interior of a Delaware estuary, with more trapped sediment being found on the creek bank levees. While drought mineral sedimentation may play a limited role in elevation stability, geomorphic stability of the salt marsh complex may be enhanced by sediment fluxes during non-drought storms similar to what we observed. However, the increase in suspended sediment concentrations that we observed during the storm may be representative of dry climate replenishment of sediment supply in tidal creeks, maintaining the geomorphic stability of the salt marsh complex by replenishing sediment on creek bank levees in the absence of SLR (Fagherazzi et al. 2013a). If marsh elevation sediment augmentation is considered as a potential management action to ameliorate the effects of SLR on salt marshes, zero net flux suggests southern California marshes will retain sediment during interventions (i.e., placement of dredge spoils on the marsh plain).

\section{Elevation Changes and SLR}

Our study sites may not be keeping pace with current rates of SLR. With negative measured surface elevation changes at Seal Beach, this marsh would not keep pace with current or 
predicted increase in SLR. At Mugu, low measured rates of elevation increases would only keep pace with the lowest predicted rate of SLR at Santa Barbara $(0.32 \mathrm{~mm} /$ year $)$. Although 449-664 days was a short sample size for monitoring elevation change (e.g., annual variation in sea level), our results suggest that to keep pace with current and predicted rates of SLR these marshes may require additional inputs of sediment which were not observed during the dry-weatherdominated study period. Lovelock et al. (2015) examined whether the length of the SET record was likely to influence their results for mangrove systems. They compared elevation gains over longer periods (mean of 5.5 years) to those over shorter periods (mean record length of 2.1 years). Rates for longer and shorter periods were highly correlated $\left(r^{2}=0.59\right)$. Further accretion and SET monitoring is needed, especially during El Niño and other storm events to assess long-term elevation change relative to sea levels.

\section{Conceptual Model of Stability to Seal Beach and Mugu}

Sediment channel flux characteristics such as (1) location of dominant sediment source, (2) the location of the wetland relative to the source, (3) the mobilization mechanism and timescale of the sediment source, and (4) the advection mechanism and timescale of the mobilized sediment are strong indicators of salt marsh stability or instability independent of SLR (Friedrichs and Perry 2001). By applying the conceptual model of marsh stability from Ganju et al. (2013) to our study sites (Fig. 2), we found that the main difference between Mugu and Seal Beach is that Mugu has an external watershed sediment source which allows for fluvial sediment mobilization and transport during flashy runoff periods (e.g., storms during El Niño). Internal and seaward sediment sources in both marshes, which are relatively small, are typically mobilized and imported landward on tidal and subtidal timescales during episodic events.

Therefore, while mechanisms promote sediment import at both marshes, Mugu is likely to be more stable in response to SLR because of its potentially larger external sediment portfolio. However, the timing and magnitude of sediment import is uncertain due to the highly unpredictable nature of El Niño. Conversely, Mugu's external sediment source may contribute little sediment to the flux during dry weather because mean discharge during the dry portion of the study period was $0.26 \mathrm{~m}^{3} / \mathrm{s}$ with a peak of $1.2 \mathrm{~m}^{3} / \mathrm{s}$ (http://waterdata.usgs.gov/ nwis), and suspended sediment concentrations are relatively lower than those observed during run-off events. Lastly, marshes with shrubby and dense vegetation, which is characteristic of Mugu, may be less prone to erosion (Boorman et al. 1998). Therefore, portions of Mugu and Seal Beach with noncordgrass vegetation cover are likely to be more stable in the face of SLR if higher rates of sediment trapping occur.

\section{Conclusions}

Quantifying and characterizing sediment fluxes and mechanisms are key components of predicting salt marsh accretion potential and resilience to projected SLR. In a region characterized by extended periods of drought (Griffin and Anchukaitis 2014), our results obtained during a representative dry weather period suggest that southern California salt marshes may be characterized by balanced sediment budgets for most of the time. When rainfall is highly concentrated, the effects of discharge and water levels on landward total sediment fluxes may be amplified and enhance geomorphic stability in light of SLR. Furthermore, exceptionally high tides enhance tidal energy which may also import small amounts of sediment. Considering that much of the sediment within the tidal creek does not reach the marsh plain in the systems studied here, projected mineral accretion is negligible based on the current flux estimates. More sediment flux, accretion, and elevation data are needed during El Niño when the frequency and intensity of storms can increase, although intense storm events may occur in non-El Niño years. However, as sea level rises, mineral sedimentation may increase if enough suspended sediment is available which could allow the marshes to persist. Conversely, in urbanized and modified estuaries, local suspended sediment may be limited resulting in a sediment deficit as sea level rises.

Acknowledgments The authors thank Tristan Edgarian, Chase Freeman, Arianna Goodman, Jimmie Lambert, Katharine Lovett, Katherine Powelson, and Yareli Sanchez for their technical expertise and field assistance. We would like to thank Region 8 US Fish \& Wildlife Service Inventory and Monitoring Program, the Southwest Climate Science Center, US Geological Survey (USGS) Western Ecological Research Center, USGS Coastal and Marine Geology Program, and USGS Climate and Land Use Research and Development Program for funding support. The authors would like to thank Andy Yuen and Kirk Gilligan, representing Seal Beach National Wildlife Refuge, Region 8 US Fish \& Wildlife Service Refuges for access and field support. We also would like to thank Martin Ruane from Naval Base Ventura County Point Mugu for access and permission to conduct study.

Open Access This article is distributed under the terms of the Creative Commons Attribution 4.0 International License (http:// creativecommons.org/licenses/by/4.0/), which permits unrestricted use, distribution, and reproduction in any medium, provided you give appropriate credit to the original author(s) and the source, provide a link to the Creative Commons license, and indicate if changes were made.

\section{References}

Beller, E., R. Grossinger, M.N. Salomon, S. Dark, E. Stein, B. Orr, P. Downs, T. Longcore, G. Coffman, A. Whipple, R. Askevold, B. Stanford, and J. Beagle. 2011. Historical ecology of the lower Santa Clara River, Ventura River, and Oxnard Plain: an analysis of terrestrial, riverine, and coastal habitats. Oakland: San Francisco Estuary Institute. 
Boorman, L.A., A. Garbutt, and D. Barratt. 1998. The role of vegetation in determining patterns of the accretion of salt marsh sediment. Geological Society, London, Special Publications 139: 389-399.

Brownlie, W., and B. Taylor. 1981. Coastal Sediment Delivery by Major Rivers in Southern California. In Sediment Management for Southern California Mountains, Coastal Plains and Shoreline. Pasadena, California: Environmental Quality Laboratory, California Institute of Technology.

Cahoon, D., and R.E. Turner. 1989. Accretion and canal impacts in a rapidly subsiding wetland II. Feldspar marker horizon technique. Estuaries 12: 260-268.

Cahoon, D.R., J.C. Lynch, and A.N. Powell. 1996. Marsh vertical accretion in a Southern California estuary, U.S.A. Estuarine, Coastal and Shelf Science 43: 19-32.

Cahoon, D.R., J.C. Lynch, B.C. Perez, B. Segura, R.D. Holland, C. Stelly, G. Stephenson, and P. Hensel. 2002. High-precision measurements of wetland sediment elevation: II. The rod surface elevation table. Journal of Sedimentary Research 72: 734-739.

Callaway, J.C., R.D. DeLaune, and W.H. Patrick Jr. 1997. Sediment accretion rates from four coastal wetlands along the Gulf of Mexico. Journal of Coastal Research 13: 181-191.

Davis, O.K. 1992. Rapid climatic change in coastal southern California inferred from pollen analysis of San Joaquin Marsh. Quaternary Research 37: 89-100.

Day Jr., J.W., L.D. Britsch, S.R. Hawes, G.P. Shaffer, D.J. Reed, and D. Cahoon. 2000. Pattern and process of land loss in the Mississippi Delta: a spatial and temporal analysis of wetland habitat change. Estuaries 23: 425-438.

Day, J.W., G.P. Kemp, D.J. Reed, D.R. Cahoon, R.M. Boumans, J.M. Suhayda, and R. Gambrell. 2011. Vegetation death and rapid loss of surface elevation in two contrasting Mississippi delta salt marshes: the role of sedimentation, autocompaction and sea-level rise. Ecological Engineering 37: 229-240.

Downing, J. 2006. Twenty-five years with OBS sensors: the good, the bad, and the ugly. Continental Shelf Research 26: 2299-2318.

Dyer, K.R. 1974. The salt balance in stratified estuaries. Estuarine and Coastal Marine Science 2: 273-281.

Fagherazzi, S., G. Mariotti, P.L. Wiberg, and K.J. McGlathery. 2013a. Marsh collapse does not require sea level rise. Oceanography 26: 70-77.

Fagherazzi, S., P. Wiberg, S. Temmerman, E. Struyf, Y. Zhao, and P. Raymond. 2013b. Fluxes of water, sediments, and biogeochemical compounds in salt marshes. Ecological Processes 2: 1-16.

French, J.R., H. Burningham, and T. Benson. 2008. Tidal and meteorological forcing of suspended sediment flux in a muddy mesotidal estuary. Estuaries and Coasts 31: 843-859.

Friedrichs, C.T., and J.E. Perry. 2001. Tidal Salt Marsh Morphodynamics: A Synthesis. Journal of Coastal Research Special Issue: 7-37.

Ganju, N.K., and D.H. Schoellhamer. 2006. Annual sediment flux estimates in a tidal strait using surrogate measurements. Estuarine, Coastal and Shelf Science 69: 165-178.

Ganju, N.K., D.H. Schoellhamer, and B.A. Bergamaschi. 2005. Suspended sediment fluxes in a tidal wetland: measurement, controlling factors, and error analysis. Estuaries 28: 812-822.

Ganju, N.K., N.J. Nidzieko, and M.L. Kirwan. 2013. Inferring tidal wetland stability from channel sediment fluxes: observations and a conceptual model. Journal of Geophysical Research, Earth Surface 118: $1-14$.

Gardner, L.R., and B. Kjerfve. 2006. Tidal fluxes of nutrients and suspended sediments at the North Inlet-Winyah Bay National Estuarine Research Reserve. Estuarine, Coastal and Shelf Science 70: 682-692.

Geyer, W.R., J.D. Woodruff, and P. Traykovski. 2001. Sediment transport and trapping in the Hudson River estuary. Estuaries 24: 670-679.
Graham, S.A., and I.A. Mendelssohn. 2014. Coastal wetland stability maintained through counterbalancing accretionary responses to chronic nutrient enrichment. Ecology 95: 3271-3283.

Griffin, D., and K.J. Anchukaitis. 2014. How unusual is the 2012-2014 California drought? Geophysical Research Letters 41: 9017-9023.

Grossinger, R., E. Stein, K. Cayce, R. Askevold, S. Dark, and A. Whipple. 2011. Historical wetlands of the southern California coast: an atlas of US coast survey $t$-sheets, 1851-1889. Oakland: San Francisco Estuary Institute.

Helsel, D.R., and R.M. Hirsch. 1992. Statistical methods in water resources. The Netherlands: Elsevier Science Publications.

Inter-Agency Committee on Water Resources Subcommittee On Sedimentation. 1961. The single-stage sampler for suspendedsediment. Minneapolis: St. Anthony Falls Hydraulics Laboratory.

Kirwan, M.L., and S.M. Mudd. 2012. Response of salt-marsh carbon accumulation to climate change. Nature 489: 550-553.

Kirwan, M.L., and A.B. Murray. 2007. A coupled geomorphic and ecological model of tidal marsh evolution. Proceedings of the National Academy of Sciences 104: 6118-6122.

Lovelock, C.E., D.R. Cahoon, D.A. Friess, G.R. Guntenspergen, K.W. Krauss, R. Reef, K. Rogers, M. Saunders, F. Sidlk, A. Swales, N. Saintilan, L.X. Thuyen, and T. Triet. 2015. The vulnerability of Indo-Pacific mangrove forests to sea level rise. Nature 526: 559-563.

MacDonald, G.M., and R.A. Case. 2005. Variations in the Pacific Decadal Oscillation over the past millennium. Geophysical Research Letters 32: L08703.

MacDonald, G.M., D.W. Stahle, J.V. Diaz, N. Beer, S.J. Busby, J. Cerano-Paredes, J.E. Cole, E.R. Cook, G. Endfield, G. GutierrezGarcia, B. Hall, V. Magan, D.M. Meko, M. Méndez-Pérez, D.J. Sauchyn, E. Watson, and C.A. Woodhouse. 2008. Climate warming and 21 st-century drought in southwestern North America. EOS Transactions American Geophysical Union 89: 82.

Morris, J.T., P.V. Sundareshwar, C.T. Nietch, B. Kjerfve, and D.R. Cahoon. 2002. Responses of coastal wetlands to rising sea level. Ecology 83: 2869-2877.

Moskalski, S.M., and C.K. Sommerfield. 2012. Suspended sediment deposition and trapping efficiency in a Delaware salt marsh. Geomorphology 139: 195-204.

Mudd, S.M. 2011. The life and death of salt marshes in response to anthropogenic disturbance of sediment supply. Geology 39: 511-512.

Mudie, P.J., and R. Byrne. 1980. Pollen evidence for historic sedimentation rates in California coastal marshes. Estuarine and Coastal Marine Science 10: 305-316.

National Resource Council. 2012. Sea-level rise for the coasts of California, Oregon, and Washington: past, present, and future. Washington D.C.: The National Academies Press.

Onuf, C.P. 1987. The ecology of Mugu Lagoon, California: an estuarine profile, 122. Washington D.C: United States Fish and Wildlife Services.

Rasmussen, P.P., J.R. Gray, G.D. Glysson, and A.C. Ziegler. 2009. Guidelines and Procedures for Computing Time-Series Suspended Sediment Concentrations and Loads from In-Stream TurbiditySensor and Streamflow Data. In U.S. Geological Survey Techniques and Methods, book 3, chapter C4, 52.

Redfield, A.C. 1972. Development of a New England salt marsh. Ecological Monographs 42: 201-237.

Stein, E.D., S. Dark, T. Longcore, N. Hall, M. Beland, R. Grossinger, J. Casanova, and M. Sutula. 2007. Historical Ecology and Landscape Change of the San Gabriel River and Floodplain. In SCCWRP Technical Report. Laguna Beach, CA: Southern California Coastal Water Research Project.

Sutherland, T.F., P.M. Lane, C.L. Amos, and J. Downing. 2000. The calibration of optical backscatter sensors for suspended sediment of varying darkness levels. Marine Geology 162: 587-597. 
Takekawa, J.Y., K.M. Thorne, K.J. Buffington, C.M. Freeman, and G. Block. 2014. Evaluation of subterranean subsidence at Seal Beach National Wildlife Refuge. In Unpublished Data Summary Report, 24. Vallejo, CA: United States Geological Survey.

Turner, R.E., J.J. Baustian, E.M. Swenson, and J.S. Spicer. 2006. Wetland sedimentation from Hurricanes Katrina and Rita. Science 314: 449-452.

U.S. Environmental Protection Agency. 1971. Residue, non-filterable: test method 160: 2 .

U.S. Environmental Protection Agency. 1993. Total Suspended Solids, Mass Balance, Volatile Suspended Solids. ESS Method 340.2.

Van Wijnen, H.J., and J.P. Bakker. 2001. Long-term surface elevation change in salt marshes: a prediction of marsh response to future sea level rise. Estuarine, Coastal and Shelf Science 51: 381-390.

Wallace, K., J. Callaway, and J. Zedler. 2005. Evolution of tidal creek networks in a high sedimentation environment: a 5-year experiment at Tijuana Estuary, California. Estuaries 28: 795-811.
Warrick, J.A., and K.L. Farnsworth. 2009a. Dispersal of river sediment in the Southern California Bight. Geological Society of America Special Papers 454: 53-67.

Warrick, J.A., and K.L. Farnsworth. 2009b. Sources of sediment to the coastal waters of the Southern California Bight. Geological Society of America Special Papers 454: 39-52.

Willis, C.M., and G.B. Griggs. 2003. Reductions in fluvial sediment discharge by coastal dams in California and implications for beach sustainability. The Journal of Geology 111: 167-182.

Zembal, R., and S.M. Hoffman. 2010. A survey of the Belding's savannah sparrow (Passerculus sandwichensis beldingi) in California 2010. Sacramento: California Department of Fish and Game.

Zembal, R., S.M. Hoffman, and J. Konecny. 2013. Status and distribution of the Light-footed Clapper rail in California. 2013 Season, 22. Sacramento: California Department of Fish and Wildlife. 